\title{
TEACHING ENGLISH PRONUNCIATION USING TONGUE TWISTER
}

Prasetyawan Aji Sugiharto ${ }^{1}$, Yan Imam Santoso ${ }^{2}$, Maila Huda Shofyana ${ }^{3}$

1,2,3 STKIP Muhammadiyah Batang

Email: as.prasetyawan@mbstkip.ac.id

\section{ABSTRACT}

This study was aim to know how tongue twister can enhance students' pronunciation ability at the first semester English Education Study Program STKIP Muhammadiyah Batang in academic year 2021/2022. This study conducted at the first semester of English Education study program that consist of 35 students as sample. This is a quantitative research. The researcher uses preexperimental design using "one-group pretest-posttest design. The researcher uses pre-test and post-test to collect the data. Based on the calculation, the result of t-value is 3.965. In addition, the result on the mean score of post-test is higher than the mean score of pre-test $(70.71>64.28)$. Then, the researcher consults the critical value to the t-table using the 5\% (0.05) alpha level significance and the degree of freedom is 1.67 . It shows that the t-value is higher than t-table (3.965>1.67). It means that Tongue Twister is effective to enhance students' pronunciation ability for the first semester students of English Education Study Program STKIP Muhammadiyah Batang. The use of tongue twister make student more active and their pronunciation ability was improved.

Keywords: teaching, English pronunciation, tongue twister.

(c) (1) This work is licensed under Creative Commons Attribution License 4.0 CC-BY International license

\section{INTRODUCTION}

\subsection{Introduction}

Language is a means to give or exchange information; news, idea or opinions, through language people learn from one another the things they want to know. One of the languages is English. It is a compulsory subject in Indonesia that must be learned by the Indonesian students from Elementary School up to University. Learning English as a foreign language is not easy to understand. We have to know the language skills such as listening, speaking, reading, and writing while language components are, such as grammar, vocabulary and pronunciation. 
Speaking and pronunciation is the thing that cannot be separated in English language communication.

Prommak (2010) states pronunciation is an integrated part of language learning. Good pronunciation will produce good speaking so that communication can be occurred well but not at all. (Gilakjani, 2012) also states that pronunciation is an integral part of foreign language learning since it directly affects learners' communicative competence as well as performance. Sometimes Indonesian students get confused to differentiate in pronouncing English vowels and consonant, which are short sounds and which are long sounds because the existence of differences between mother tongue and the target language. In this case, the students need improving communicative competence in order to understand pronunciation. (Sitoresmi, 2016) argues that the students' need a unique and challenging activity to boost their interest in learning English.

In learning English, the teacher must have the ability to explain that English sound systems are different from Indonesian. Teaching pronunciation is not easy because the wrong pronunciation has consequences information will not be accepted clearly. A lot of factors that caused the difficulty or wrong pronouncing the English word, such as passive students speaking in the class, unfamiliar word and lack of listening and practicing. (Beltrán-Herrera et al., 2016) stated that to teach pronunciation especially for ESL students, teachers should teach the letter sound, letter formation, identifying the sounds in a word.

According to (Carmen, 2010), a tongue-twister is a sequence of words that is difficult to pronounce quickly and correctly. English tongue twisters may be used for our students to enhance their accent and also by speech therapists to help those with speech difficulties. (Putri, 2018) stated that in practicing tongue twister, the teacher can make the students focus on one activity, because students will feel attract with the tongue twister technique because it is new to them. (Prošić-Santovac, 2009) argues that tongue twister can be as a potentially ideal pronunciation exercise because tongue twister has a repetition of a sound and has own stress, rhythm and intonation of natural speech. To strengthen their speech skill, people can be practicing tongue twister when learning English. (Lutfiani, 2017) said that the faster a person can say the tongue twister without slipping up, the stronger their language skills become.

Principally in learning pronunciation need a strategy, so the teacher must create the better atmosphere for encourage student to improve their skill, critical thinking, creativity, collaborative, communicative, and literacy. Furthermore, this study aim to know how effective 
teaching English pronunciation using Tongue Twister for the first semester student of English Education study program STKIP Muhammadiyah Batang

\subsection{Research questions}

From the problems above, the researcher formulated the question of this study, how effective the teaching English pronunciation using tongue twister for the first semester students of English education study program STKIP Muhammadiyah Batang?

\subsection{Significance of the study}

The researcher supposed to make contribution to the teaching English in university. For teacher, they can make and apply the variation of learning activity and can develop their teaching approach so it can be reducing false of the student's pronunciation. The result of the study also contributes to other researcher to give references to the writer to conduct further researcher

\section{METHOD}

\subsection{Research Design}

This is a quantitative research. The researcher uses pre-experimental design using "onegroup pretest-posttest design. The researcher uses pre-test and post-test to collect the data. The researcher explained the direction as clearly as possible to make the students understand the materials being tested. The researcher used one class to describe whether the use of tongue twister is effective or not to improve students' pronunciation ability for the first semester students English Education study program STKIP Muhammdiyah Batang. The basic table of the study was explained as follows:

\section{Table 1. One-Group Pre and Post test Design}

\section{$\begin{array}{llll}\mathrm{G} & 01 & \mathrm{X} & 02\end{array}$}

Where:

G : Group of Subject

01 : Pre test

X : Treatment

02 : Post test

The population of this research was all of students English Education Study Program STKIP Muhammadiyah Batang. In order to select the sample, the purposing sampling technique would be implemented. Sample is a subject of individuals from a given population is research 
field. According to (Dörnyei \& Csizér, 2012), sample is the group of people whom researchers actually examine. The sample is 35 students of first semester students of English Education Study Program of STKIP Muhammadiyah Batang.

In this research, the researcher uses test as the instrument of collecting the data. The researcher uses pre-test and post-test in getting the data. Pre-test which is given before the treatment, and post-test which is given after the treatment.

In analyzing the data, the researcher carried out some steps, there are: preparing the research instrument, giving pre-test, giving treatment and giving post-test. This analysis is related to the computation in answering the problem statement and the hypothesis testing presents. To analyze the data, the researcher applies an appropriate technique to find out the influence of both variables of this research. The data were analyzed by the use of a dependent tTest for comparing the results of between pre-test and post-test.

\section{FINDINGS AND DISCUSSION}

\subsection{Findings}

The following table would present the analysis of students' pronunciation ability in pretest. The analysis was done by taking the score of post-test.

Table 2. Pronunciation ability results of pre-test and post-test

\begin{tabular}{lcc}
\hline \multicolumn{1}{c}{ Statistic } & Pre-test & Post-test \\
\hline Mean & 64.28 & 70.71 \\
Median & 62.5 & 72.5 \\
Modus & 60 & 70 \\
Range & 30 & 30 \\
Standart Deviation & 9.00 & 9.71 \\
Highest score & 80 & 85 \\
Lowest score & 50 & 55 \\
Variance & 81.09 & 94.32 \\
\hline
\end{tabular}

The pronunciation ability result of pre-test and post-test was reported here in the form of chart. The vertical line with numbers beside showed the percentage of students for each grade. The horizon line showed the grade of pronunciation ability of the scores obtained by the students.

The following chart showed the pronunciation ability result of pre-test and post-test. 


\section{Chart 1. The chart of pronunciation ability result of pre-test and post-test}

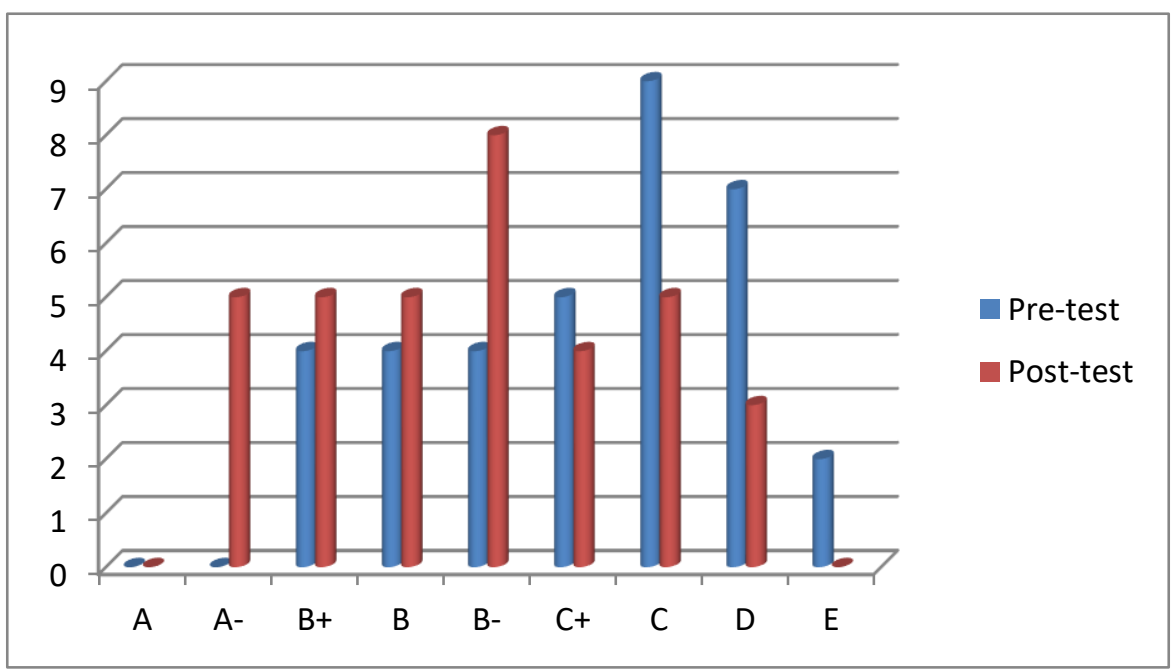

This chart showed the pronunciation ability result of pre-test and post-test. The chart showed a significant effect between pre-test and post-test.

The following is the statistical analysis of the test results. SPSS 16.00 computation was used to get the results.

Table 3. The Summary of Normality Test Based on SPSS

\begin{tabular}{llrr}
\hline \multicolumn{4}{c}{ One-Sample Kolmogorov-Smirnov Test } \\
& & Pre-test & \multicolumn{1}{c}{ Post-test } \\
\hline $\mathrm{N}$ & & 35 & 35 \\
Normal & Mean & 64.2857 & 70.7143 \\
Parameters & Std. Deviation & 9.00513 & 9.71225 \\
Most & Absolute & .197 & .128 \\
Extreme & Positive & .197 & .122 \\
Differences & Negative & -.112 & -.128 \\
Kolmogorov-Smirnov Z & 1.167 & .756 \\
Asymp. Sig. (2-tailed) & .131 & .617
\end{tabular}

Test distribution was Normal

Based on the computation above, it showed that both pre-test and post-test (Asymp. Sig. (2-tailed)) were higher than 0.05. They were 0.131 and 0.617 . It means that the data was normal.

The calculation of the mean score of pre-test and post-test was 64.28 and 70.71. If we compare the two means, it was clear that the mean of the post-test is higher than the mean of pretest. The difference between the two means is 6.43. After computing, the researcher got the $\mathrm{t}$ value. It was 3.965. It indicated that the treatment was effective. It would be interpreted in hypothesis testing. 
In testing hypothesis, the researcher used the level of significance to minimize the false conclusion of the research. In this research, the researcher used the level of significance $5 \%$ level. It means that the falseness of conclusion was 95\%. In testing hypothesis, the researcher commonly faced with the null hypothesis. By using the null hypothesis, the hypothesis statement will be easier to be proved.

\subsection{Discussion}

The researcher was going to describe to interpretation of research result about descriptive analysis and inferential analysis. The pronunciation ability result of pre-test. The highest score of the students of pre-test of the first semester students of English Education Study Program of STKIP Muhammadiyah Batang was 80 and the lowest one was 50. The mean of pre-test was 64.28 and the standard deviation of it was 9.00. It means that the students of pre-test of the first semester students of English Education Study Program STKIP Muhammadiyah Batang have sufficient result on their pronunciation ability. This reflects that student was passive and got difficulties in learning pronunciation. The result of the pre-test this in line with (Lutfiani, 2017) stated that the more practice in learning pronunciation was needed.

From 35 samples, the researcher took the mark, there were 2 students $(5.71 \%)$ belong to low category, 7 students (20\%) belong to fairly sufficient category, 9 students $(25.71 \%)$ belong to sufficient category, 5students $(14.28 \%)$ belong to sufficient category, 4 students $(11.42 \%)$ belong to good category, 4 students $(11.42 \%)$ belong to good category, and 4 students $(11.42 \%)$ belong to good category.

The pronunciation ability result of post-test. The highest score of the students of post-test of the first semester students of English Education Study Program of STKIP Muhammadiyah Batang was 85 and the lowest one was 55. The mean of post-test was 70.71 and the standard deviation of it was 9.71. It means that the students of post-test of the first semester students of English Education Study Program of STKIP Muhammadiyah Batang have good result on their pronunciation ability.

After receiving treatment, the students enjoyed the process of learning pronunciation well. It can be seen in the post-test where there are differences with the pre-test. The post-test was higher than pre-test. It means that teaching English pronunciation using tongue twister was improved. This result is strengthen by a study from (Kholisoh \& Farida, 2019) that giving the treatment using tongue twister influences students' ability.

From 35 samples, the researcher took the mark, there were 3 students $(8.57 \%)$ belongs to fairly sufficient category, 5 students $(14.42 \%)$ belong to sufficient category, 4 students $(11.42 \%)$ 
belong to sufficient category, 8 students $(22.85 \%)$ belong to good category, 5 students (14.28\%) belong to good category, 5 students (14.28\%) belong to good category, and 5 students (14.28 \%) belong to excellent category.

As mentioned above, the hypothesis of this research says "teaching English pronunciation using tongue twister for the first semester students of English Education Study Program of STKIP Muhammadiyah Batang is not effective". From the previous analysis, it shows that with the amount of the samples $(\mathrm{N}=35)$ and the level of significance was $5 \%$, the result of the computation of t-value is higher than the t-table that was 3.965>1.67. So, the hypothesis was accepted. It means that "teaching English pronunciation using tongue twister for the first semester students of English Education Study Program of STKIP Muhammadiyah Batang is effective". The improvement of the students' ability was significance after using tongue twister technique. The tongue twister technique was the effective way to treat student in order to improve their fluency and accuracy in speaking English (Agnes Cahaya Lestari, 2019).

After computing t-test, and after knowing that the hypothesis is accepted, the theory

meets the fact in this case. Then, from the computation exist in the previous section; the researcher concluded that teaching pronunciation using Tongue Twister is effective for first semester students of English Education Study Program of STKIP Muhammadiyah Batang, the theory is proved. The evidence was based on the significant differences result between before using tongue twister and after using tongue twister.

\section{CONCLUSIONS}

\subsection{Conclusion}

Based on the research finding which has been discussed in the previous chapter that there is effectiveness of teaching English pronunciation using Tongue Twister to improve students' ability for first semester students of English Education Study Program of STKIP Muhammadiyah Batang. This study was in line with (Bac et al., 2020) stated that the implementation of tongue twister technique in teaching pronunciation could be used in combination with many activities such as whisper tongue twister and chain reading tongue twister.

In addition, the result on the mean score of post-test is higher than the mean score of pretest $(70.71>64.28)$. The researcher got the analysis that in using tongue twister technique, the students more active during the process learning, the attention and participation was going better. (Amar et al., 2019) said students agree that using tongue twisters effectively increases their motivation to learn English. Therefore; the conclusion can be draw that the use of Tongue 
Twister as a technique to enhance students' pronunciation ability is effective to first semester students of students of English Education Study Program of STKIP Muhammadiyah Batang.

\subsection{Suggestions}

Based on the above conclusion, the researcher offers the following suggestion to teacher can apply tongue twister in teaching learning process as the technique to improve students' pronunciation, can choose an appropriate teaching technique to increase the student' interest in learning English, can use Tongue Twister as an alternative technique of teaching pronunciation to transfer the knowledge for the students. For students, should be respectfully motivated because there is an interested way to learn pronunciation from the teacher, they must learn to pronounce tongue twister quickly, correctly and without stumbling or mispronouncing by having much practice. This study is also can be information and a new reference technique in teaching English pronunciation for the other researcher.

\section{REFERENCES}

Agnes Cahaya Lestari. (2019). THE EFFECTIVENESS OF TONGUE TWISTER TECHNIQUE TO IMPROVE FLUENCY AND ACCURACY. April, 33-35. http://digilib.uinsby.ac.id/30296/1/Agnes Cahya Lestari_D75214026.pdf

Amar, L. N., Mu, F., \& Rusmanayanti, A. (2019). Students' Perceptions on the Use of Tongue Twisters in Learning Pronunciation. 1(2), 73-92.

Bac, V. D., Thi, H., Hanh, H., \& Hanh, D. M. (2020). USING TONGUE TWISTER TECHNIQUE TO IMPROVE ENGLISH PRONUNCIATION FOR THE FIRST-YEAR ENGLISH MAJOR STUDENTS AT THAI NGUYEN UNIVERSITY OF EDUCATION PHÁT

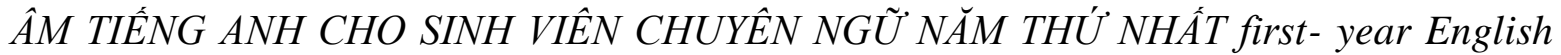
majors 'pronunciation at Thai Nguyen University of Education by using tongue twister technique; ( 2 ) to see how In Cambridge Advanced Learner 's Dictionary, tongue twister is a sentence or phrase that is several advantages of using tongue twister in - Helping students focus on the lesson and. 225(03), 189-192.

Beltrán-Herrera, M. A., Andrade-Chávez, L. L., \& Álvarez-Rojas, D. F. (2016). Pronunciation improvement in EFL young learners through phonics instruction. Praxis, 12, 52. https://doi.org/10.21676/23897856.1847

Carmen, R. (2010). Spoken English : flourish your language.

Dörnyei, Z., \& Csizér, K. (2012). How to Design and Analyze Surveys in Second Language Acquisition Research. Research Methods in Second Language Acquisition: A Practical Guide, 74-94. https://doi.org/10.1002/9781444347340.ch5 
Gilakjani, A. P. (2012). Goals of English Pronunciation Instruction. 1(1), 8. http://researchpub.org/journal/ijltr/number/vol1-no1-1.pdf

Kholisoh, A., \& Farida, A. N. (2019). The Influences of Tongue Twister in Teaching Pronunciation of Aspirated Sound [ph]. ELT Forum: Journal of English Language Teaching, 7(2), 63-72. https://doi.org/10.15294/elt.v7i2.28859

Lutfiani, D. (2017). Using Tongue Twister to Improve Students' Pronunciation. ELLITE: Journal of English Language, Literature, and Teaching, 2(2), 110-115. https://doi.org/10.32528/ellite.v2i2.1511

Prošić-Santovac, D. (2009). THE USE OF TONGUE TWISTERS IN EFL TEACHING. Review of the Faculty of Philosophy / Godisnjak Filozofskog Fakulteta, 34(1/2), 159-169. https://web.s.ebscohost.com/abstract?direct=true \&profile=ehost\&scope=site\&authtype $=$ cra wler \&jrnl $=03740730 \& A N=55567546 \& \mathrm{~h}=\mathrm{b} 5 \mathrm{R} \%$ 2bdykpLNqbToH78K41L551f7vOSCumP 8s\%2fqWPPWFNDaf\%2fkBRUCg2THODI8Kyt5asm51PVDXflg\%2btJVrxDZEw\%3d\%3d $\& \mathrm{crl}=\mathrm{c} \&$ resultNs $=$ AdminWebAuth\&resultLocal=ErrCrlNotAuth\&crlhashurl=login. aspx $\% 3$ fdirect $\% 3$ dtrue $\% 26$ profile $\% 3$ dehost $\% 26$ scope $\% 3$ dsite $\% 26$ authtype $\% 3$ dcrawler $\% 26 \mathrm{jrn} 1 \% 3 \mathrm{~d}$ $03740730 \% 26 \mathrm{AN} \% 3 \mathrm{~d} 55567546$

Putri, Y. a. (2018). Improving Students' pronunciation by Using Tongue Twister technique. Journal Pendidikan Dan Pembelajaran Khatulistiwa, 7(11), 1-9. http://jurnal.untan.ac.id/index.php/jpdpb/article/view/29732/75676579231

Sitoresmi, U. (2016). Tongue twisters in pronunciation class. Prosiding ICTTE FKIP UNS 2015, 1(1), 589-592. 